\title{
The Language of Plague and its Regional Perspectives: The Case of Medieval Germany
}

\author{
KAY PETER JANKRIFT
}

"In the year of our Lord 1350 the greatest mortality of mankind, called the epidemia, ruled in the world so that the number of living men was insufficient to bury the others," noted the chronicler Florence of Wevelinghoven in the middle of the fourteenth century. ${ }^{1}$ An eyewitness of the Black Death, he later became bishop of Münster in Westphalia (1364-78) and bishop of Utrecht (1378-93). ${ }^{2}$ The Westphalian cleric was only one among many to describe in these or in very similar words the unimaginable mortality caused by the Black Death. Contemporary records from all over Europe tell the same story: the disease appeared everywhere in the world and depopulated the cities, leaving too few survivors to bury the countless dead. ${ }^{3}$ It is this image of a "worldwide" pandemic of the Black Death, together with, to a lesser extent, descriptions of the subsequent outbreaks of plague by contemporaries, which has dominated the historian's view of medieval epidemics until today. But what one may call the language of plague, the language of the sources, comprises universal and particular aspects at the same time. As European society is not uniform (despite all attempts of the administration of the European Union) and has never been so in the past, one has to ask how far did the different geographical and cultural backgrounds of chroniclers and medical practitioners influence the language of plague? Are there any differences in the attitudes towards the disease and in the ways of dealing with medieval epidemics, even if the same words are used? Did an Italian really have exactly the same view of plague as a Spaniard, an Englishman or a German? What finally inspired me to ask these questions within the context of plague were several examples of such differences in sources of the period concerning another medical problem, the disease (or rather the diseases) contemporaries used to identify as leprosy.

\section{Sunlight, Moonshine and Leprosy}

A medical compendium written in the late fifteenth century for Charles VIII (1470-98), king of France, recommended examining by the bright light of the moon those who were

Priv. Doz. Dr phil. Kay Peter Jankrift, Institut für Geschichte der Medizin der Robert Bosch Stiftung, Straußweg 17, 70184 Stuttgart, Germany.

\footnotetext{
1 “Anno domini m.ccc.l. viguit in universo mundo mortalitas hominum permaxima successive, que epydemia vocabatur, ita quod vix unus homo alium sufficiebat sepelire.” Julius Ficker (ed.), Die Geschichtsquellen des Bisthums Münster. Vol. 1: Die Münsterischen Chroniken des Mittelalters, Münster, 1851, p. 49.

${ }^{2}$ Harm Klueting, Geschichte Westfalens. Das Land zwischen Rhein und Weser, Paderborn, Bonifatius, 1998, p. 68 .

${ }^{3}$ Klaus Bergdolt, Der Schwarze Tod in Europa. Die Große Pest und das Ende des Mittelalters, Munich, C H Beck, 1995, pp. 39, 65. Ole J Benedictow, The Black Death 1346-1353: the complete history, Woodbridge, Boydell Press, 2004. Neithard Bulst, 'Der Schwarze Tod im 14. Jahrhundert', in Mischa Meier (ed.), Pest. Die Geschichte eines Menschheitstraumas, Stuttgart, Klett-Cotta, 2005, pp. 142-61.
} 


\section{Kay Peter Jankrift}

suspected of being afflicted with leprosy. ${ }^{4}$ The text advised medical practitioners in charge of such an examination to put a healthy person next to the suspected leper in order to compare their outer appearance. While a healthy person exposed to moonshine would appear just pale, the skin of a leprosy sufferer would look like speckled marble. In Germany, however, leprosy suspects were always examined during the day and only when there was enough sunlight. Sixteenth-century statutes from the Melaten leperhouse outside the walls of Cologne ordered such examinations to be performed between one and a half hours after sunrise and one and a half hours before sunset. ${ }^{5}$ Men, women and children from cities all over north-western Germany were brought at that time to be examined at Melaten, the oldest leper-house in the region, founded during the last two decades of the twelfth century. ${ }^{6}$ According to the statutes, the examiners were all leprosy sufferers themselves, who were considered the most experienced inhabitants of the leperhouse. Before admitting a new member to their household, most leprosaria in Westphalia and the Rhineland demanded that the candidate should provide a certificate from Melaten identifying him as a leprosy sufferer. ${ }^{7}$ Most town councils accepted this certificate as the only valid document for admission to their communal leper-houses. Unfortunately, no document remains to show in detail how the so called examen leprosorum was carried out by the leprous examiners at Melaten. The faculty of medicine at the University of Cologne, however, whose doctors started to examine suspected leprosy sufferers in the fifteenth century, kept detailed records of these examinations. ${ }^{8}$ Most of them noted the hour at which the examination took place. Very often this was around noon, when the sun stands at its zenith and there is almost no shadow. On 17 September 1515, for example, the commission met at 1 p.m. in the house of Doctor Heinrich Andree of Sittard (d. 1551) in order to examine William of Oen, marshal of Duke Charles of Geldern. ${ }^{9}$ The doctors found several buboes on his face and on his extremities. They described his eyes as uncommonly round. Moreover, they remarked on a number of possible symptoms of leprosy. Yet, they decided to wait and to examine the marshal once again the following summer. This second examination took place on 16 July 1516 in the presence of Doctors Andree, Bau, Walter Heinrichs of Dordrecht, and Broech. This time the examiners did not hesitate. They declared William of Oen to be afflicted with leprosy. Examinations took place also during the winter, care being taken that they were carried out around noon. On 23 December 1520, the commission also met at 1 p.m. in Andree's the house to examine Johannes Sal, a lay

\footnotetext{
${ }^{4}$ Paris, Bibliothèque Nationale, Ms FR 12323, fol. 16r. Kay Peter Jankrift, Mit Gott und Schwarzer Magie. Medizin im Mittelalter, Darmstadt, Wissenschaftliche Buchgesellschaft, 2005, p. 134.

5 Irmgard Hort, 'Aussätzige in Melaten: Regeln zur Krankheitsdiagnose, um 1540/1580', in Joachim Deeters and Johannes Helmrath (eds), Quellen zur Geschichte der Stadt Köln, Bd.2: Spätes Mittelalter und Frühe Neuzeit (1396-1794), Köln, Bachem, 1996, pp. 168-73.

${ }^{6}$ Johannes Asen, Das Leprosenhaus Melaten bei Köln, Bonn, J Bach, 1908. Gregor Heinrich Klövekom, Der Aussatz in Köln, Munich, K Thiemig, 1966, p. 67.

${ }^{7}$ Kay Peter Jankrift, 'Jost Heerde. Das Schicksal eines Lepraverdächtigen in Münster', Die Klapper. Mitteilungen der Gesellschaft für Leprakunde, 1998, 6: 3-5. Thomas Schwabach, 'Ein bemerkenswerter Lepra-Untersuchungsfall vor der Medizinischen Fakultät der Universität Köln in der ersten Hälfte des 16. Jahrhunderts', ibid., pp. 8-10.

${ }^{8}$ Hermann Keussen, 'Beiträge zur Geschichte der Kölner Lepra-Untersuchungen', Lepra. Bibliotheca internationalis, 1913, 14: 80-112.

${ }^{9}$ Jankrift, op. cit., note 4 above, p. 135.
} 


\section{The Language of Plague and its Regional Perspectives}

brother in the house of the Observants in Cologne. ${ }^{10} \mathrm{He}$ was found to be free of leprosy, but infected with the French Disease. Therefore, the doctors ordered him to consult a medical practitioner for treatment and to be suspended from any further service in the kitchen.

These examples show that in the late fifteenth and early sixteenth centuries the common opinion about how to examine those who, according to contemporary conceptions of this disease, were afflicted with leprosy differed considerably in France and Germany. Such differences in writing about or treating the same medical problem in different places in Europe are not restricted to any one period. They have always existed and continue to do so today, as described in a rather humorous way by a German living with his family in France in 1998. ${ }^{11}$ His new-born daughter cries at night and so the desperate father consults French and German books on children's health and care. During his sleepless nights, he becomes more and more troubled by the fact that the advice in the books is often contradictory. While, for example, the German text states that new-born children are awake for on average 8 hours, the French one says that they sleep on average for 19 hours during the first weeks. "Do not be afraid to let babies cry for about 10 minutes. Then they will fall asleep by themselves", advises the French book. The German one states just the opposite: "Never let a baby cry!" 12

Another modern example is the "medical problem" that the French call "crise du foie", crisis of the liver - a health problem unknown in German. The list of such examples seems endless. With regard to our original question concerning the language of plague, it is likely that people from different cultural and geographical backgrounds associated "plague" with different ideas.

\section{The "Whole World" and One's Own Town}

Sometimes the "whole world" mentioned in most of the chronicles suddenly becomes very small. Time and again, chroniclers, copying from earlier works, transformed the information of their predecessors so that it conformed to their own viewpoints, and they transferred epidemics that occurred elsewhere to the region or town where they themselves lived. ${ }^{13}$ The following example illustrates how a report about an epidemic disease taken up by several chroniclers can be transformed over the centuries. In his chronicle of the world entitled Liber de rebus et temporibus memorabilioribus, the Dominican Heinrich of Herford (d. 1370), who lived in his Order's house in Minden in eastern Westphalia, mentioned famine and great mortality throughout the "world" in the year 1003: "There was such a great famine and mortality in all the world that the vital spirit

\footnotetext{
${ }^{10}$ Ibid., p. 134.

${ }^{11}$ Ernst-Ludwig von Thadden, 'Oh Baby! Oh bébé! Frankreich und Deutschland in der Nacht', Papa liebt Dich!, Frankfurt am Main, Schölling, 1998, pp. 24-31.

12 "Ne craignez pas de le laisser pleurer une dizaine de minutes, il arrivera à s'endormir de lui-même"; "Man sollte ein Baby niemals schreien lassen", ibid., p. 28.

${ }^{13}$ Gert Melville, 'Kompilation, Fiktion und Diskurs. Aspekte zur heuristischen Methode der mittelalterlichen Geschichtsschreiber', in Christian Meier and Jörn Rüsen (eds), Historische Methode, Munich, Taschenbuch, 1988, pp. 133-53.
} 


\section{Kay Peter Jankrift}

departed from those burying the dead and they fell into the graves together with them."14 Heinrich reports an event that is supposed to have happened more than 300 years before his own lifetime. He took his information from the chronicle of the Benedictine monk Sigebert of Gembloux (d. 1121), who described that very mortality for the year 1006. The combination of famine and mortality probably allows the assumption that Sigebert repeated what he had read about the mass intoxication of Saint Anthony's fire that he himself witnessed in 1089. ${ }^{15}$ It was not the "whole world", but Sigebert's home region of Lorraine, Wallonia, Flanders, Champagne, the Ile-de-France and other French provinces that suffered repeatedly from famine accompanied by Saint Anthony's fire during the tenth and eleventh centuries. ${ }^{16}$ The Annales Xantenses mention an unusually high mortality in 857 probably caused by the disease: "There was a great disease of swelling blisters among the people which consumed them in such a terrible putrefaction that the members separated from the body and fell off before death." 17 This short notice remains the only testimony of the disease east of the Rhine before the early twelfth century. ${ }^{18}$ However, the information that Heinrich of Herford had taken from Sigebert of Gembloux was repeated by later chroniclers from Minden and adapted to their records of local history. The so-called Jüngere Bischofschronik (the Later chronicle of the bishops), written after the middle of the fifteenth century, tells the story of a great famine all over the world during the lifetime of Bishop Ramward (996-1002). ${ }^{19}$ The text repeats almost word for word the statement of Heinrich of Herford that those who buried the dead also lost the breath of life. But now this event is embedded among other different information about local history. Finally, the description in the Chronicon domesticum et gentile recorded by Heinrich Piel (d. 1580), a member of the town council, in the second half of the sixteenth century, places the entire event in the context of Minden's history. ${ }^{20}$ So within the course of 600 years, the chroniclers changed an unusual mortality caused by disease in Lorraine and parts of France into a

\footnotetext{
14 “Fames et mortalitas tam graviter per totum pene orbem invaluit, ut sepelientium tedio vivi spiritum adhuc trahentes cum mortalitas abruerentur". August Potthast (ed.), Liber de rebus memorabilioribus sive Chronicon Henrici de Hervordia (bis 1355), Göttingen, Dieterich, 1859, p. 131. About Heinrich of Herford, see Klaus Peter Schumann, Heinrich von Herford. Enzyklopädische Gelehrsamkeit und universalhistorische Konzeption im Dienste dominikanischer Studienbedürfnisse, Münster, Aschendorff, 1996.

${ }^{15}$ Sigebert of Gembloux, Sigeberti Gemblacensis monachi opera omnia accedit chronicon Polonorum, Paris, Garnier Fratres, 1880, p. 224. Kay Peter Jankrift, 'Epidemien im Hochmittelalter', in Meier (ed.), op. cit., note 3 above, pp. 129-41, on p. 132.

${ }^{16}$ Jean-Noël Biraben, 'Das medizinische Denken und die Krankheiten in Europa', in Mirko D Grmek (ed.), Die Geschichte des medizinischen Denkens. Antike und Mittelalter, Munich, C H Beck, 1996, pp. 356-401, on p. 391; Adalbert Mischlewski, 'Das Antoniusfeuer in Mittelalter und früher Neuzeit in Westeuropa', in Neithard Bulst and Robert Delort, Maladies et société (XII - XVIII siècles). Actes du Colloque de Bielefeld, Paris, Presses du CNRS, 1989, pp. 249-68, on p. 250.

17 "Plaga magna vesicarum turgentium grassatur in populo, et detestabili eoas putredine consupsit it ut menbra [sic] dissolute, ante mortem deciderent." Georg Heinrich Pertz (ed.), Annales Xantenses, in Monumenta Germaniae Historica. Scriptores, Hanover, 1829, vol. 2, pp. 217-35, on p. 229.

${ }^{18}$ Biraben, op. cit., note 16 above, p. 391. Egon Schmitz-Cliever, 'Pest und pestilenzialische Krankheiten in der Geschichte der Reichsstadt Aachen', Zeitschrift des Aachener Geschichtsvereins, 1954/1955, 66/67: 108-68, on p. 112.

19 'Die jüngere Bischofschronik', in Klemens Löffler (ed.), Die Bischofschroniken des Mittelalters. Hermann's von Lerbeck Catalogus episcoporum Mindensium und seine Ableitungen, Münster, Aschendorff, 1917, pp. 91-263, on p. 126.

${ }^{20}$ Martin Krieg (ed.), Das chronicon domesticum et gentile des Heinrich Piel, Münster, Aschendorff, 1981, p. 25.
} 


\section{The Language of Plague and its Regional Perspectives}

local event in eastern Westphalia. This example, to which others could be added, pleads for comparative regional studies of plague and other epidemics, in order to identify their real dimensions and effects as well as to correct the image of often "worldwide" events. A closer and more critical look at the sources shows that even the Black Death did not strike everywhere.

\section{The "Whole World", the Black Death and Plague: A Plea for a Regional Approach in the History of Epidemic Diseases}

At the end of the fourteenth century, Tilemann Elhen of Wolfhagen wrote in his chronicle of the city of Limburg, "I have myself seen and experienced four of the great plague epidemics." ${ }^{21}$ Born in 1347, he did not count the Black Death among the four outbreaks of plague that he himself witnessed during his lifetime. According to his chronology, the second wave of high mortality occurred in 1356 and was followed by three others in 1365, 1383 and 1395. The chronicler states that the epidemic disease of 1356 was exactly the same as the one in 1350, the Black Death, while the later outbreaks seemed to be more moderate. A number of contemporary documents - chronicles, protocols of the town councils, account books and charters, to name but the most prominent types-from several cities of the Rhineland and Westphalia prove these data to be more or less exact. ${ }^{22}$ The density of cities was very high in this part of the Regnum Teutonicum. It was possible to leave a city such as Dortmund in the morning and, to reach Essen, Duisburg or Soest within a day. This favoured the spread of diseases with short times of incubation, such as what is nowadays defined as plague. Thus, it is not surprising that the sources reveal almost forty outbreaks of epidemic diseases in the region between the rivers Weser and Rhine from 1350 to 1600. There is not enough space here for a detailed discussion of the considerable social and economic impact of these events in the Rhineland and Westphalia. Summing up the effects of plague in the region, one can see a change of social structures. A chronicle from Cologne reports, for example, that following the plague of 1451 there were more marriages than usual in the city, because many wives lost their husbands and many husbands their wives. ${ }^{23}$ Such situations caused the urban upper class to marry partners of a lower class. Trade and production were interrupted during the time of the outbreak. Craftsmen among the victims were sometimes hard to replace.

All this seems to indicate a close connection between the frequency and intensity of outbreaks of plague and economic and social development in the Regnum Teutonicum. It is known that important cities in the south such as Nuremberg and Würzburg were spared from the Black Death, as well as Prague, residence of the Emperor Charles IV. ${ }^{24}$ The same

\footnotetext{
21 “Der großen pestilencien han ich vir gesehen unde irlebet." Arthur Wyss (ed.), Die Limburger Chronik des Tilemann Elhen von Wolfhagen, Hanover and Leipzig, Hahn, 1883, p. 14.

${ }^{22}$ Kay Peter Jankrift, Up dat god sich aver uns verbarmen wolde. Formen, Strukturen und Entwicklungen der Auseinandersetzung mit Seuchen in westfälischen und rheinischen Städten im Mittelalter. 9.-16. Jh. , Bielefeld, Verlag für Regionalgeschichte, 2007.

${ }^{23}$ Hermann Cardauns (ed.), Cronica van der hilliger stat von Coellen bis 1499 (Koelhoffsche Chronik). Die Chroniken der deutschen Städte vom 14. bis ins 16. Jahrhundert, Bd. 14, Die Chroniken der niederrheinischen Städte, Bd.3: Cöln, Leipzig, 1877, p. 796.

${ }^{24}$ Bergdolt, op. cit., note 3 above, p. 82 .
} 


\section{Kay Peter Jankrift}

seems to be true for Augsburg, where the tax lists do not indicate any remarkable changes at the time of the Black Death. ${ }^{25}$ This means that the most important economic centres of the south were not disturbed by an unusual mortality and continued their development—at least for some years-without any major break. It was not the "whole world", or even the whole of Germany, that suffered from the effects of the Black Death. Regional studies in other countries of Europe might well confirm this picture and explain developments that have so far remained unnoticed, as historians tend to regard the history of plague and its language as much too uniform. Comparative regional studies that also include iconographical data are needed in order to establish a more realistic picture of plague and to understand the development of its language.

${ }^{25}$ I thank Professor Rolf Kießling, University of Augsburg, and Raphael Krug, who studied the tax lists, for this information. 